\title{
PENGOLAHAN CITRA DIGITAL DAN HISTOGRAM DENGAN PHYTON DAN TEXT EDITOR PHYCHARM
}

\author{
Silvia Ratna \\ Fakultas Teknologi Informasi, Universitas Islam Kalimantan Muhammad Arsyad Al Banjari \\ Email : silvia@fti.uniska-bjm.ac.id
}

\begin{abstract}
ABSTRAK
Citra merupakan salah satu bentuk informasi yang diperlukan manusia selain teks, suara dan video.Informasi yang terkandung dalam sebuah citra dapat diinterpretasikan berbeda-beda oleh manusia satu dengan yang lain.

Citra analog dihasilkan dari alat akuisisi citra analog, contohnya adalah mata manusia dan kamera analog. Gambaran yang tertangkap oleh mata manusia dan foto atau film yang tertangkap oleh kamera analog merupakan contoh dari citra analog.. Citra digital merupakan representasi dari fungsi intensitas cahaya dalam bentuk diskrit pada bidang dua dimensi. Citra tersusun oleh sekumpulan piksel (picture element) yang memiliki koordinat $(\mathrm{x}, \mathrm{y})$ dan amplitudo $\mathrm{f}(\mathrm{x}, \mathrm{y})$. Koordinat $(\mathrm{x}, \mathrm{y})$ menunjukkan letak/posisi piksel dalam suatu citra, sedangkan amplitudo $\mathrm{f}(\mathrm{x}, \mathrm{y})$ menunjukkan nilai intensitas warna citra. Pengolahan citra (image Processing) adalah proses mengolah piksel-piksel di dalam citra digital yang digunakan untuk tujuan tertentu. Awalnya pengolahan citra dilakukan untuk memperbaiki kualitas citra, dengan berkembangnya dunia komputasi yang ditandai dengan semakin meningkatnya kapasitas dan kemampuan komputer memungkinkan manusia dapat Mengambil informasi dari suatu citra.

Pengolahan Citra Digital (Digital Image Processing) merupakan bidang ilmu yang mempelajari tentang bagaimana suatu citra itu dibentuk, diolah, dan dianalisis sehingga menghasilkan informasi yang dapat dipahami oleh manusia, sedangkan Histogram citra adalah representasi grafik yang menyatakan distribusi nilai-nilai warna atau intensitas piksel-piksel di dalam citra. Frekuensi kemunculan nilai intensitas piksel pada suatu citra dapat diketahui melalui 50 Pengolahan Citra histogram citra tersebut. Pengolahan Citra Digital ini menggunakan bahasa pemrograman Phyton dan Phycharm, yang fungsinya melihat hasil perubahan citra, Histogram pada gambar dengan menggunakan Phyton dan phycharm
\end{abstract}

Kata kunci: Citra, Image Processing, Digital Image Processing, Histogram 


\section{PENDAHULUAN}

A. Pengolahan Citra Digital (Digital Image Processing) merupakan disiplin ilmu yang mempelajari teknik dalam mengolah citra, citra yang dimaksud adalah merupakan gambar diam (foto) atau gambar yang bergerak (seperti video yang direkam). Sedangkan arti digital adalah pengolahan citra/gambar dilakukan menggunakan komputer secara digital. RGB adalah singkatan dari Red-Green-Blue, merupakan tiga warna dasar (primary colors) yang secara umum dijadikan acuan warna lainnya Dari basis RGB, kita dapat mengkonversi warna menjadi kode-kode angka yang membuat warna tersebut akan tampil universal. Komputer sudah mengemas informasi warna menjadi model warna yang sama sehingga membuat pengolahan warna RGB dapat dilakukan dengan mudah.

B. Python adalah satu dari bahasa pemrograman tingkat tinggi yang bersifat interpreter, interaktif, object-oriented dan dapat beroperasi di hampir semua platform seperti keluarga Linux, Windows, Mac, dan platform lainnya. Python adalah salah satu bahasa pemrograman tingkat tinggi yang mudah dipelajari karena sintaks yang jelas dan elegan, yang dikombinasikan dengan penggunaan modul-modul yang mempunyai struktur data tingkat tinggi, efisien, dan siap langsung digunakan . Source code aplikasi dalam bahasa pemrograman Python biasanya akan dikompilasi menjadi format perantara yang dikenal sebagai byte code yang selanjutnya akan dieksekusi.

C. OpenCV merupakan singkatan dari Open Computer Vision, merupakan sebuah library gratis yang diperuntukkan untuk melakukan image processing yang dikembangkan oleh Intel Corporation. Tujuannya adalah agar komputer mempunyai kemampuan yang mirip dengan cara pengolahan visual pada manusia. Modul pustaka OpenCV ini dibangun dengan sangat kuat dan fleksibel untuk menyelesaikan sebagian besar masalah computer vision yang solusinya memang sudah tersedia, seperti memotong citra (cropping), meningkatkan kualitas citra dengan memodifikasi kecerahan, ketajaman, kontras, mendeteksi bentuk, segmentasi citra, mendeteksi objek yang bergerak, mengenali objek, dan lain-lain .

D. PhyCharm adalah Editor yang bisa digunakan selain IDLE, kelebihan nya adalah lebih ringan dan praktis, karena Phycharm sendiri dibangun menggunakan phyton, maka dukungan terhadap bahasa pemrograman tersebut cukup lengkap dan praktis.

\section{RUMUSAN MASALAH}

Berdasarkan latar belakang judul yang dipilih, maka perumusan masalah dalam penelitian ini adalah :

1. Membuat dan menguji Algoritma pengolahan citra dengan menggunakan Phyton dan PhyCharm

2. Membuat dan menguji Algoritma pengolahan Histogram dengan menggunakan Phyton dan PhyCharm

\section{TUJUAN PENELITIAN}

Tujuan yang ingin dicapai dalam penelitian ini adalah membandingkan bagaimana hasil Pengolahan citra pada suatu gambar dengan pengolahan warna dan ruang yang berbeda dengan menggunakan bahasa pemrograman Phyton dan text editor phycharm.

\section{METODE PENELITIAN}

Metode yang digunakan dalam
membangun penelitian ini adalah
menggunakan metode Rekayasa.

Langkah-langkah pembuatan perangkat lunak ini antara lain : 
1. Mempersiapkan aplikasi Phyton yang sudah terinstal dengan Open $\mathrm{Cv}$

2. Menginstal Phycharm

3. Menganalisa kebutuhan-kebutuhan pada saat membuat aplikasi, Ex : Picture extention, jpg , png

4. Merancang interface untuk perangkat lunak simulasi.

5. Melakukan pengujian dan pengetesan Algoritma.

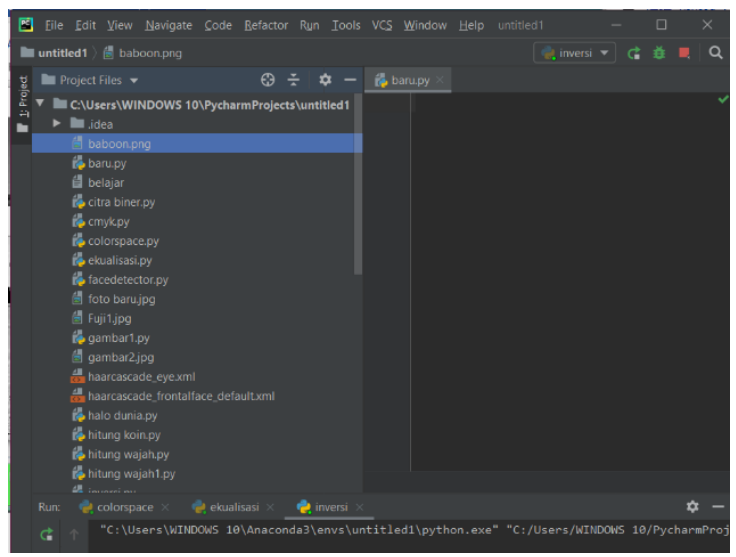

\section{ANALISA HASIL DAN PEMBAHASAN}

Gambar 2. Text Editor PhyCharm

\section{Gambaran Flowchart pengolahan}

\section{Citra}

Step pemrosesan ditunjukan dan digambarkan dengan Flowchart berikut
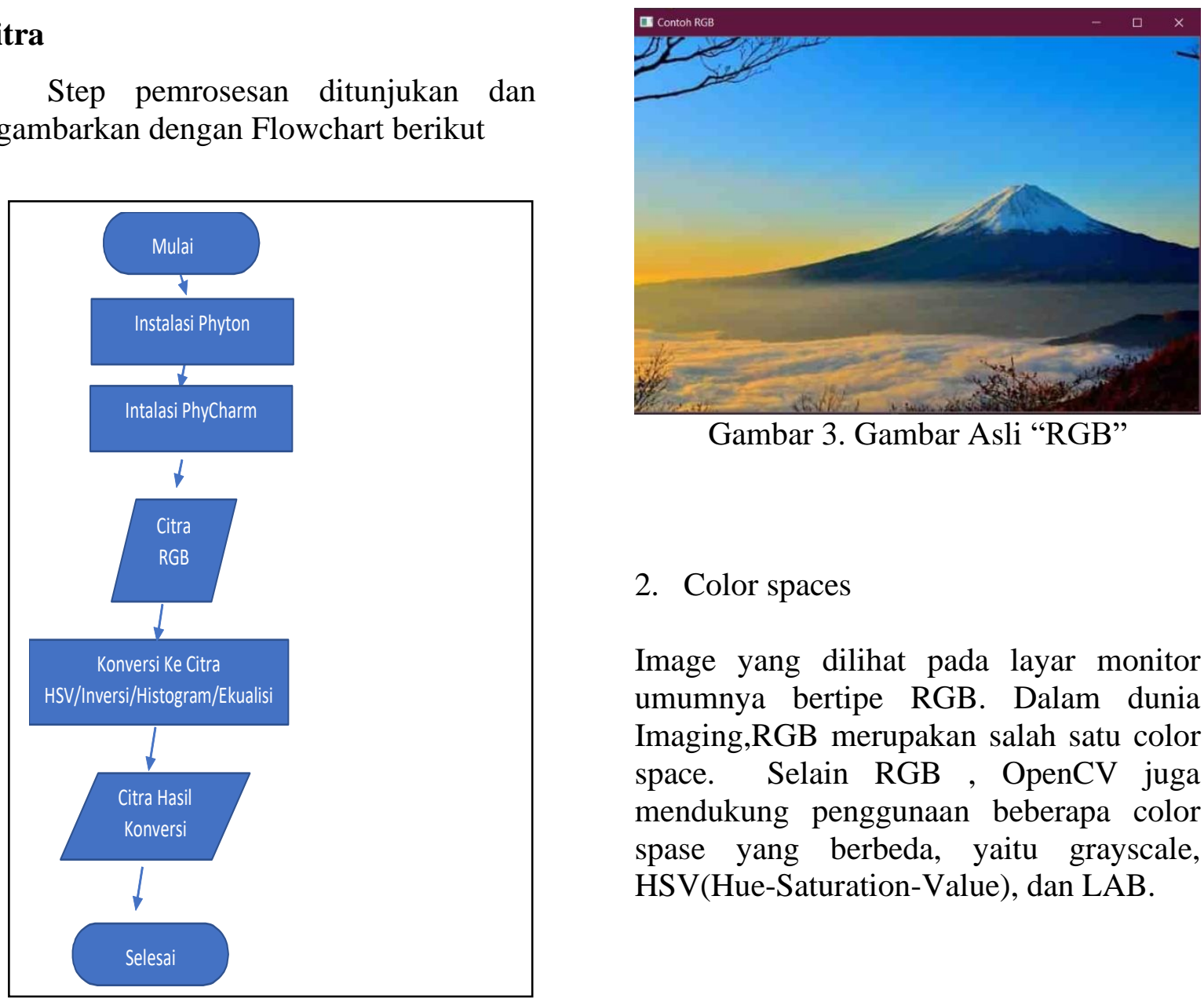

Gambar 3. Gambar Asli "RGB"

\section{Color spaces}

Image yang dilihat pada layar monitor umumnya bertipe RGB. Dalam dunia Imaging, RGB merupakan salah satu color space. Selain RGB, OpenCV juga mendukung penggunaan beberapa color spase yang berbeda, yaitu grayscale, HSV(Hue-Saturation-Value), dan LAB.

Gambar 1. Flow Diagram 


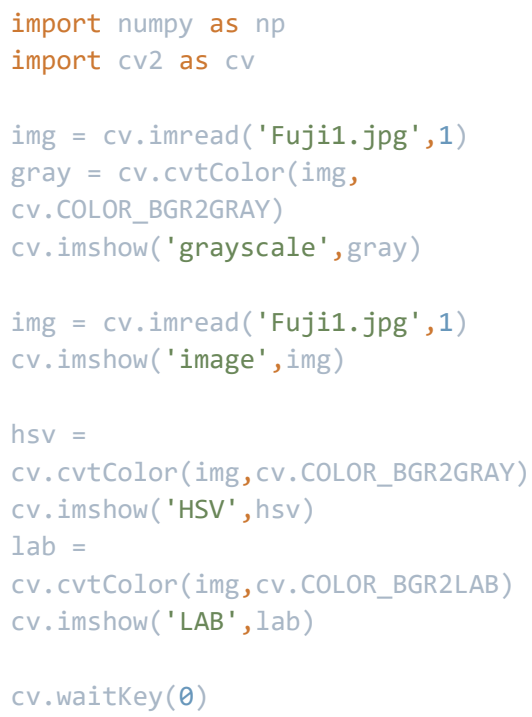

Gambar 4. Kode program

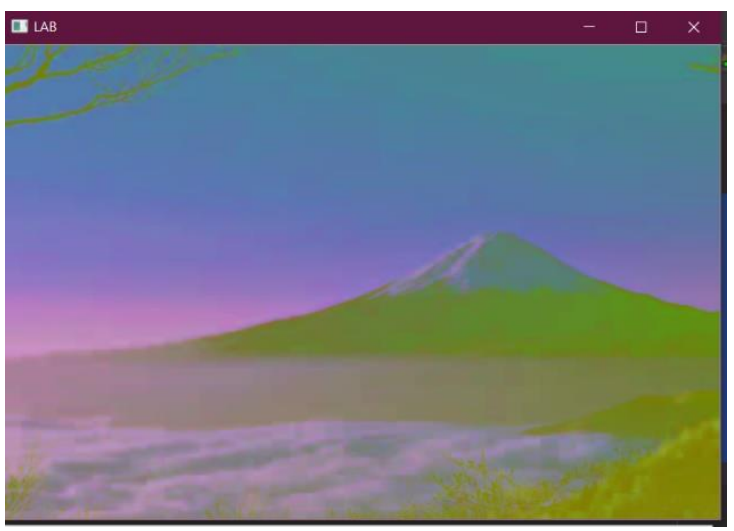

Gambar 5. Hasil Lab

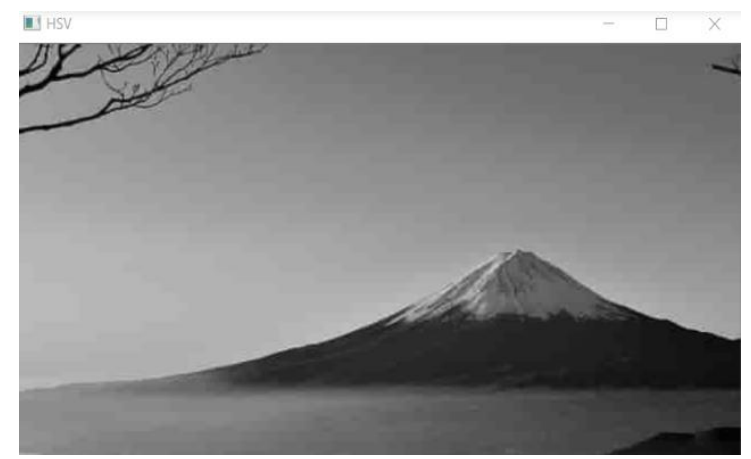

Gambar 6. Hasil HSV

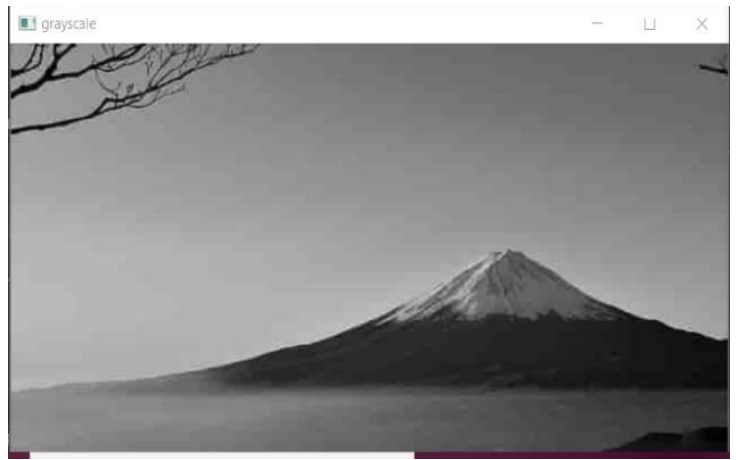

Gambar 7. Hasil Grayscale

\section{Inversi Citra}

Inversi Citra berarti membalik citra. Dibidang fotografi dengan film, inversi menghasilkan gambar negatif.

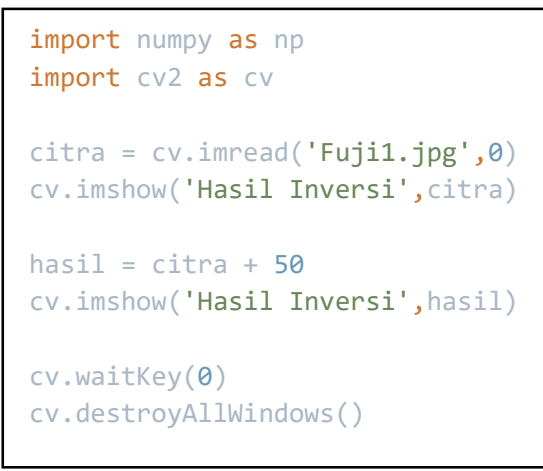

Gambar 8. Kode program Inversi

Hasil dari inversi dapat dilihat sebagai berikut :

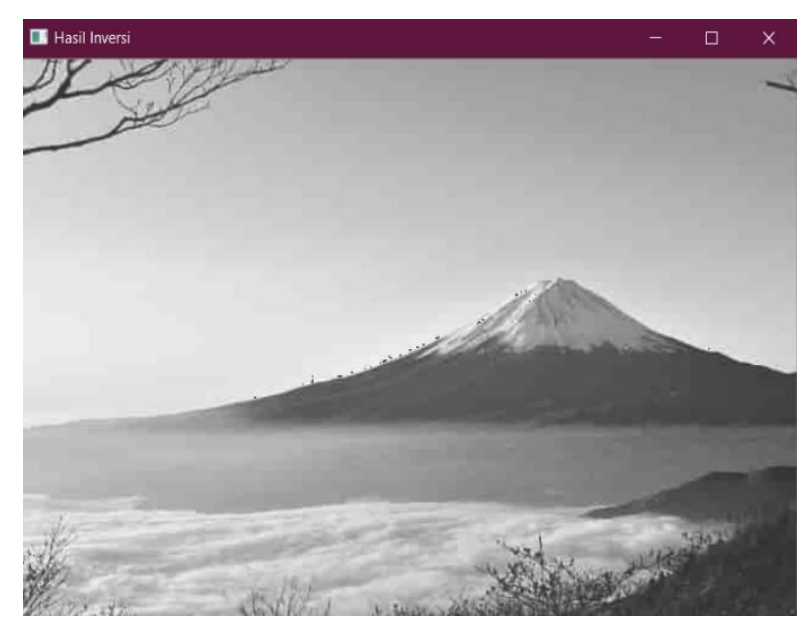

Gambar 9. Hasil Inversi 


\section{Histogram}

Histogram adalah grafik yang mneggambarkan distribusi intensitas pada citra dan merupakan perangkat yang digunakan unuk melakukan analisis citra.

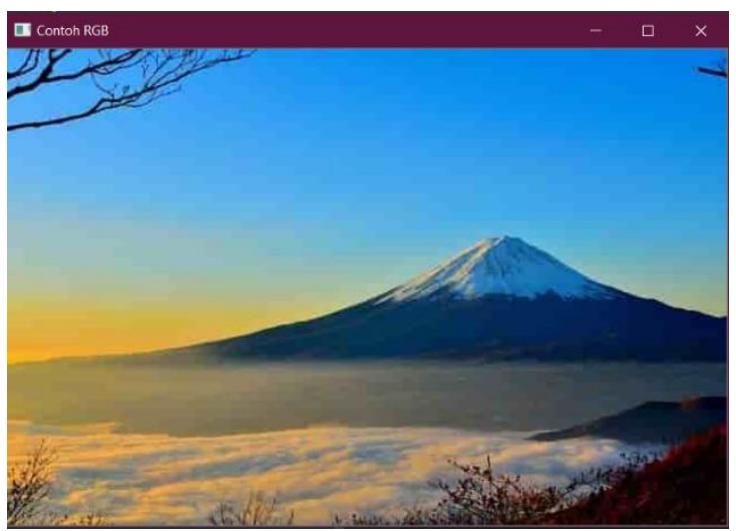

Gambar 10. Gambar Asli Fuji1“RGB”

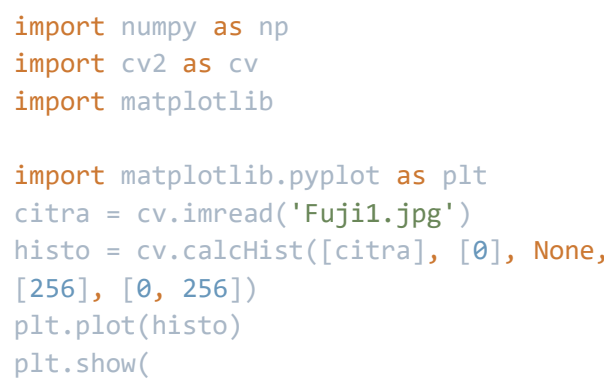

Gambar 11. Kode program Histogram 1

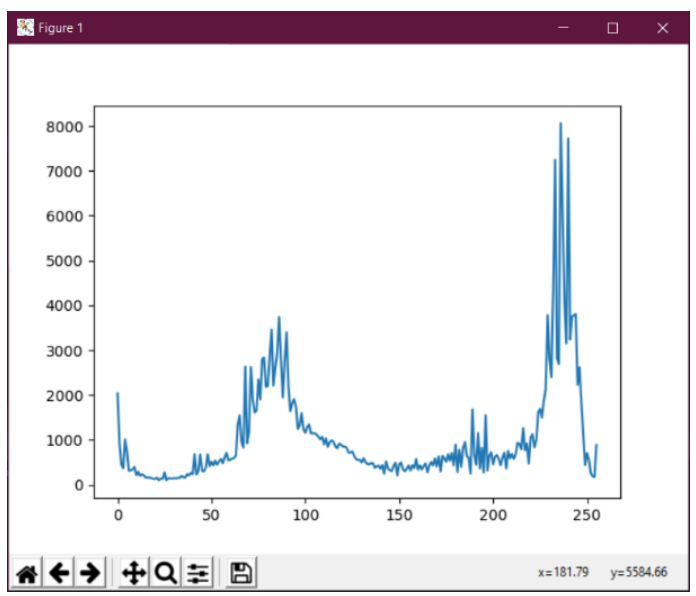

Gambar 12. Hasil Histogram 1

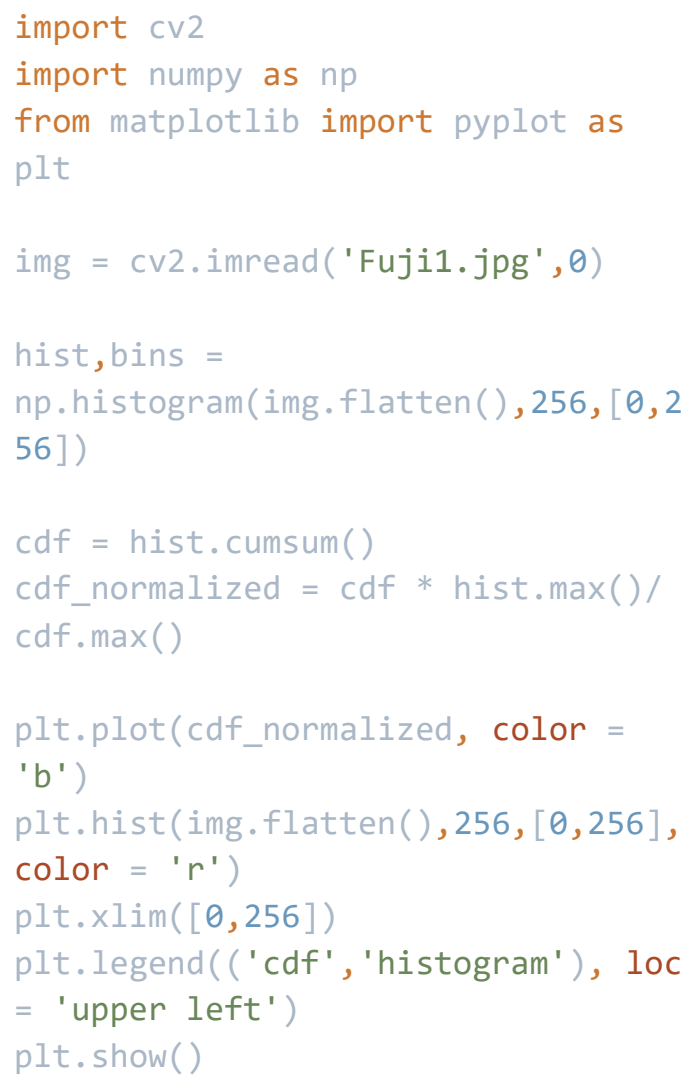

Gambar 13. Kode program Histogram 2

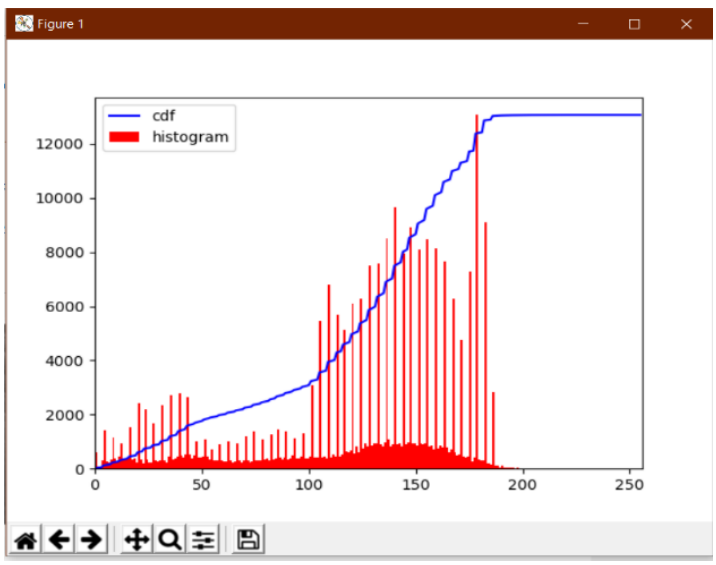

Gambar 14. Hasil Histogram 2

5. Ekualisi Histogram merupakan suatu cara yang bertujuan untuk memperoleh histogram dengan intensitas terdistribusi secara beragam pada citra. Proses ekualisi adalah proses pengolah citra dan menggunakan kode program 
seperti pada gambar 15 dan menghasilkan citra pada gambar 16

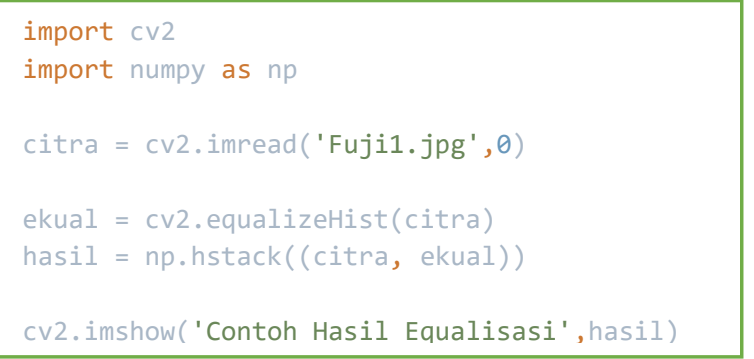

Gambar 15. Kode program Ekualisi

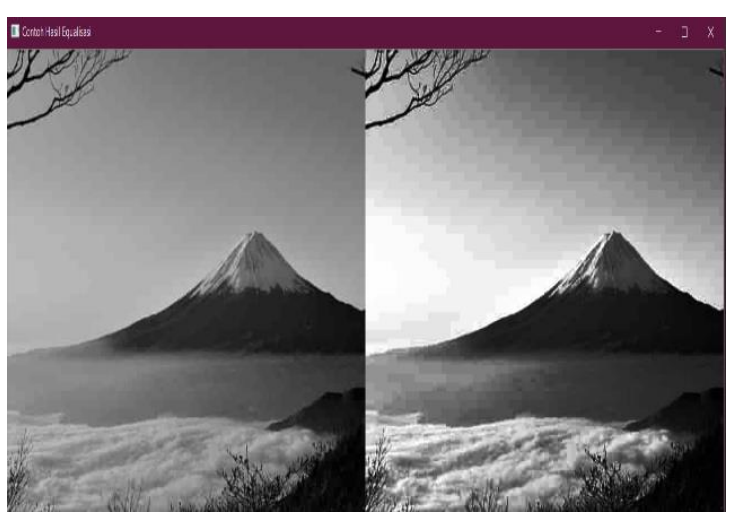

Gambar 16. Hasil Ekualisi

\section{PENUTUP}

\section{Kesimpulan}

Dari hasil pengolahan citra dan histogram dapat dibedakan hasil dan dapat diambil gambar sesuai dengan keperluan pengguna gambar tersebut.

\section{Saran}

Berdasarkan hasil pengolahan citra dan Histogram, saran yang ingin di sampaikan penulis adalah :

1. Dapat dilanjutkan dengan Membuat Interface Visual untuk mengelola pemrosesan perubahan Citra dan histogram dengan memanfaatkan Tkinter, OpenCV dan Matplotlib.
2. Dapat dikembangkan pengolahan citra dan histogram sesuai dengan keperluan citra dengan memanfaatkan fungsifungsi dan library yang disediakan oleh Phyton.

3. Pengembangan penggunaan bahasa pemrograman phyton untuk pengelolaan dan pemrosesan data.

\section{DAFTAR PUSTAKA}

Budi Rahardjo . (2019) Pemrograman Phyton Bandung.Informatika.

Hanna Arini Parhusip. (2019). Pemrograman Pyton. Yogyakarta: Andi Offset.

Hasibuan, Z. A. (2007). Metodelogi Penelitian Pada Bidang Ilmu Komputer dan Teknologi

Informasi. Jakarta.

Jogiyanto, \& Hartono. (2009). Analisis \& Desain Sistem Informasi. Yogyakarta. Andi Ofset.

Jubilee Enterprise Jogiyanto, \& Hartono. (2009). Analisis \& Desain Sistem Informasi. Yogyakarta. Andi Ofset.

Kadir, Abdul. (2019). Pemrograman OpenCV \& Phyton. PT.Gramedia. Jakarta.

Rosihan Ari Yuana. (2019). Phyton Kasus Big Data. Yogyakarta: CV.Loko media. 